\title{
The Joe Meyer Estate \#1 Site (41SM73) on Saline Creek in the Upper Neches River Basin in East Texas
}

Timothy K. Perttula

Heritage Research Center, Stephen F. Austin State University

Follow this and additional works at: https://scholarworks.sfasu.edu/ita

Part of the American Material Culture Commons, Archaeological Anthropology Commons, Environmental Studies Commons, Other American Studies Commons, Other Arts and Humanities Commons, Other History of Art, Architecture, and Archaeology Commons, and the United States History Commons

Tell us how this article helped you.

This Article is brought to you for free and open access by the Center for Regional Heritage Research at SFA ScholarWorks. It has been accepted for inclusion in Index of Texas Archaeology: Open Access Gray Literature from the Lone Star State by an authorized editor of SFA ScholarWorks. For more information, please contact cdsscholarworks@sfasu.edu. 


\section{The Joe Meyer Estate \#1 Site (41SM73) on Saline Creek in the Upper Neches River Basin in East Texas}

\section{Creative Commons License}

\section{(c) (1) \&}

This work is licensed under a Creative Commons Attribution-NonCommercial 4.0 International License 


\title{
The Joe Meyer Estate \#1 Site (41SM73) on Saline Creek in the Upper Neches River Basin in East Texas
}

\author{
Timothy K. Perttula
}

\section{INTRODUCTION}

The Joe Meyer Estate \#1 site (41SM73) is an ancestral Caddo settlement and cemetery on an upland landform west of Saline Creek, a southern-flowing tributary of the Neches River in the upper Neches River basin (Figure 1). In the spring of 1957 members of the East Texas Archeological Society (ETAS; see Walters 2014), including John Mulligan, Sam Whiteside, Derrell Sanders, and Jowell Proctor, had located the site and commenced excavations. The site had substantial midden deposits as well as Caddo burial features.

W. A. Davis and E. Mott Davis of The University of Texas visited the site in April 1957, took notes on the burial features and associated funerary offerings, and obtained a surface collection of artifacts. The summer of 1957, LeRoy Johnson, Jr. visited the site and obtained a surface collection as part of a broader survey of Blackburn Crossing Reservoir (now Lake Palestine) on the Neches River (Johnson 1961:219-221).

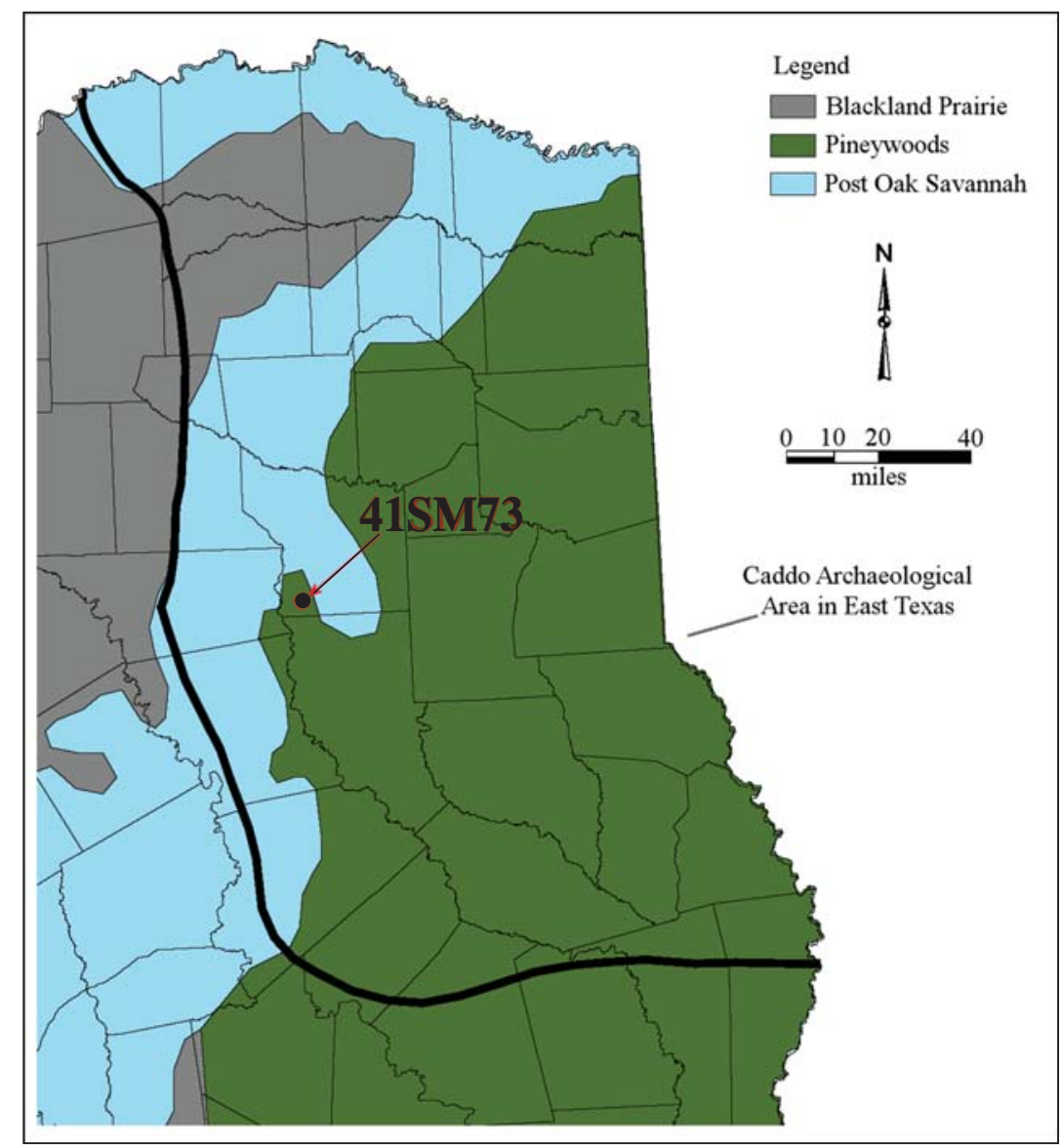

Figure 1. The location of the Joe Meyer Estate \#1 site (41SM73) in East Texas. 
In December 1957, E. Mott Davis visited the site again, at which time ETAS members had excavated two test pits $(\mathrm{A}$ and $\mathrm{B})$ in the midden deposits.

In June 1969 George Kegley and Dan Witter returned to the site, and made a small surface collection. They also noted that at least 25 Caddo burials (some, if not all, of apparent post-A.D. 1400 age based on the finding of Poynor Engraved vessels) had been excavated in 1966-1967 in another cemetery at the site; one of the main excavators of this cemetery was William "Red" McFarland of Whitehouse, Texas, a well known East Texas digger; this same cemetery may have also been explored by Buddy Jones and ETAS members some years before, where two burials were excavated (Perttula et al. 2013:53-55). Finally, in August 1969 and March 1970, archaeologists from Southern Methodist University (SMU) returned to the Joe Meyer Estate \#1 site as part of a more intensive survey of proposed Lake Palestine (see Anderson 1972). A large assemblage of ceramic sherds $(n=596)$ was collected from the surface of the site as part of this survey (Anderson 1972:Table 4). About 86 percent of the decorated sherds in this assemblage were from brushed jars (Anderson 1972:Table 13), suggesting the sherds were collected from a Late Caddo occupation area, probably an occupation dating to the 17th century given the very high proportion of brushed sherds in the decorated sherd assemblage (Perttula et al. 2011). The Joe Meyer Estate \#1 site was not one of the sites selected for excavation by SMU before construction of the reservoir (Anderson et al. 1974), likely because the site was not to be inundated by the reservoir flood pool (see Anderson 1972:Figure 1). There have been no professional archaeological investigations at the site since 1970.

\section{SITE SETTING}

The Joe Meyer Estate site covers about 3-5 acres of an upland ridge on the west side of Saline Creek, overlooking the creek floodplain and creek channel (Figure 2); Saline Creek is a southern-flowing tributary of the Neches River. The site is marked by a midden deposit between $60-100 \mathrm{~cm}$ in thickness, with abundant sherds, animal bones, and pieces of mussel shell. In one part of the midden, seven ancestral Caddo burial features dating to the Early Caddo period (ca. A.D. 900-1200) were identified and excavated (Burials 1-6 and Multiple Burial 1). Funerary offerings were present with each of the burial features, and the ETAS work in 1957 had also uncovered a Late Caddo period (ca. A.D. 1400-1650) Poynor Engraved vessel from an undisclosed location within the site. This find may be the first evidence that there was also a Lake Caddo period Frankston phase cemetery on the site, and this cemetery was apparently excavated in the 1960s (see above).

\section{CADDO BURIAL FEATURES}

Six of the burial features at the Joe Meyer Estate \#1 site are individual burials (Burials 1-6) placed in a single north-south row in an extended supine position with the head of the deceased facing generally west (Burials 1-5) or northwest (Burial 6) (Figure 3). The area excavated to exposed the burial features was ca. $6 \mathrm{~m}$ (north-south) x $9 \mathrm{~m}$ (east-west) in size. These burials lay in the lowest part of the midden deposits, from ca. 81-102 cm bs. Funerary offerings with the burials included 12 ceramic vessels-between one to four vessels per burial; one of the vessels (unfortunately, which vessel is not known) contained a green clay pigment and mussel shells.

The multiple burial west of Burials 5 and 6 (see Figure 3) had four individuals laid out in an extended supine position, with their heads facing west. The multiple burial was in the upper part of the midden, with a bottom depth of only ca. $61 \mathrm{~cm} \mathrm{bs}$. Based simply on depth of this burial feature and the likelihood that the burial pit encountered and disturbed Burials 5 and 6 (see Figure 3), it is probable that the multiple burial was the latest burial feature in this cemetery. Funerary offerings included three ceramic vessels. 


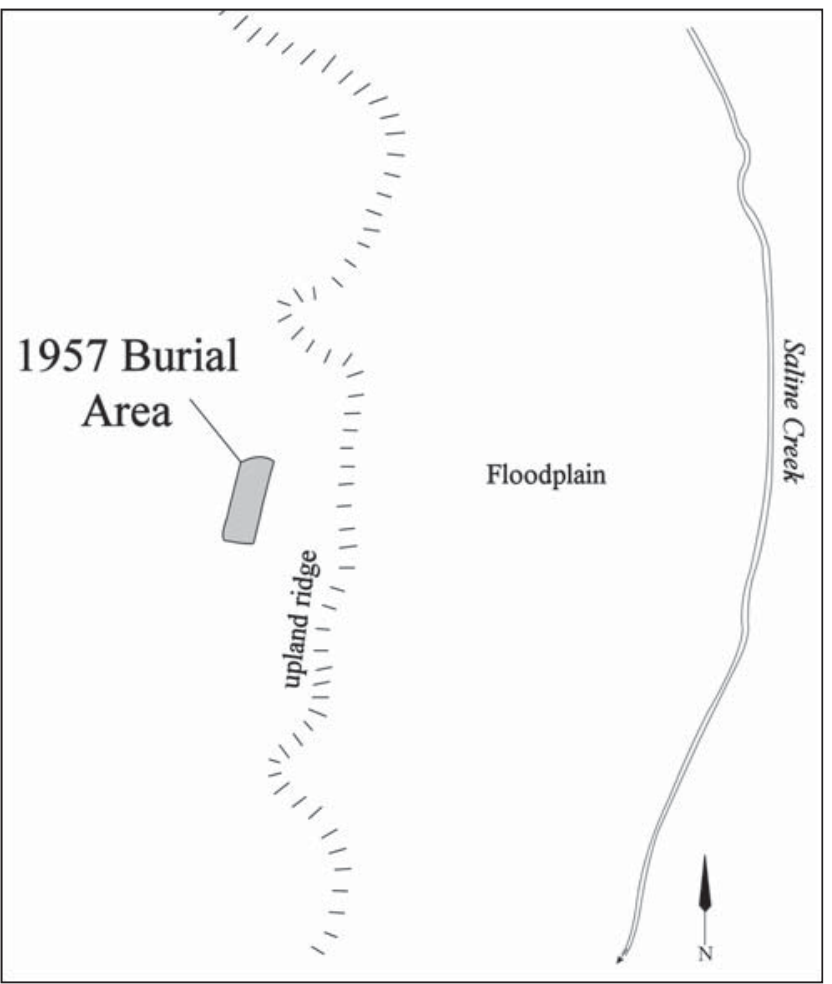

Figure 2. The Joe Meyer Estate \#1 site (41SM73) in the Saline Creek valley.

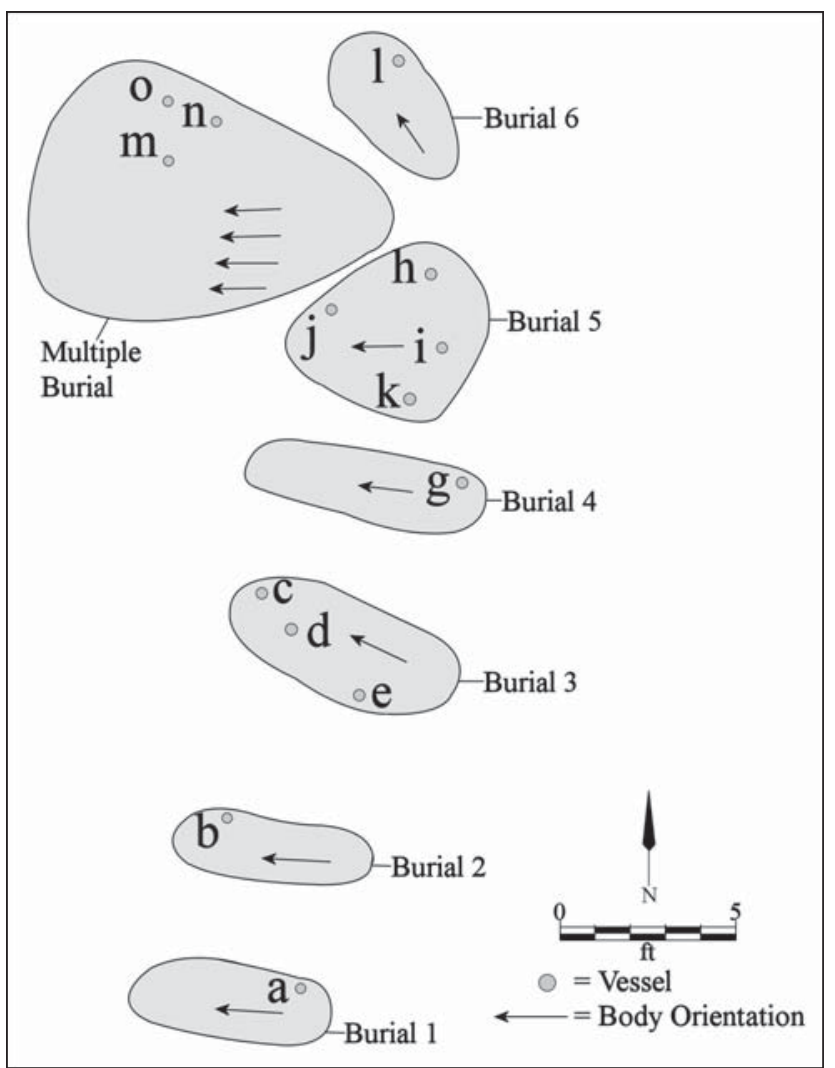

Figure 3. Plan of the cemetery at the Joe Meyer Estate \#1 site (41SM73). 


\section{ARTIFACT ASSEMBLAGE}

The artifact assemblage from the Joe Meyer Estate \#1 site includes 15 ceramic vessels or portions of vessels from the Early Caddo period burial features, 820 ceramic sherds from midden deposits on the site, one Red River long-stemmed pipe sherd, and two Woodland period dart points.

\section{Ceramic Vessels from Burial Features}

The 15 ceramic vessels or portions of vessels in the burial features include bottles $(n=4)$, jars $(n=2)$, bowls ( $n=6)$, and carinated bowls ( $n=3)$ (Figure 4 and Table 1). Most of the vessels are plain (67 percent), but those that are decorated include a Canton Incised bowl in Burial 4 (Figure 4f), a carinated bowl in Burial 3 with a reworked rim that has alternating series of ovals with excised and cross-hatched engraved zones (Figure 5), a bottle in Burial 5 with short and widely-spaced pinched ridges on its body (Figure 4h), a Hickory Engraved bottle in the Multiple Burial (Figure 41), and a Weches Fingernail Impressed carinated bowl in the Multiple Burial (Figure 4m).

Table 1. Vessel attributes.

\begin{tabular}{lllcc}
\hline Burial No. & Vessel & Temper & Height $(\mathrm{cm})$ & Orifice Diameter (cm) \\
\hline 1 & $\mathrm{~A}$ & bone & - & $12.0^{*}$ \\
2 & $\mathrm{~B}$ & grog-bone & - & 15.0 \\
3 & $\mathrm{C}$ & bone & 10.0 & 16.0 \\
3 & $\mathrm{D}$ & bone & 10.0 & 10.0 \\
3 & $\mathrm{E}$ & bone & $* *$ & 14.0 \\
3 & $\mathrm{~F}$ & grog & 6.0 & 7.0 \\
4 & $\mathrm{G}$ & grog-bone & 7.0 & 10.0 \\
5 & $\mathrm{H}$ & - & 8.0 & 15.0 \\
5 & $\mathrm{I}$ & bone & 12.0 & 7.0 \\
5 & $\mathrm{~J}$ & bone & 6.0 & 7.0 \\
5 & $\mathrm{~K}$ & grog & 5.0 & 10.0 \\
6 & $\mathrm{~L}$ & bone & 7.0 & 5.0 \\
Multiple & $\mathrm{M}$ & grog & 24.0 & - \\
Multiple & $\mathrm{N}$ & - & - & - \\
Multiple & $\mathrm{O}$ & grog-bone & - & \\
\hline
\end{tabular}

*maximum body diameter

**reworked rim

With the exception of the Hickory Engraved bottle from the Multiple Burial (see Figure 4l), the vessels from the Early Caddo cemetery are small in size, with heights ranging from only 5.0-12.0 cm and orifice diameters ranging between $7.0-16.0 \mathrm{~cm}$. None of the vessels would have held more than 1 liter of contents. Vessels are tempered with grog $(n=3)$, grog and bone $(n=3)$, and bone $(n=7)$; the use of burned bone as a temper is apparently considerable in the vessels when compared to the vessel sherds from the midden, as Johnson had noted on 1957 inventory forms that grog was the most common temper and that bone temper was rare (see below).

In addition to these vessels from Early Caddo burial contexts, it is known that there were Late Caddo Frankston phase burial features excavated in another cemetery at the Joe Meyer Estate \#1 site. The only ceramic vessel from the Frankston phase burials that can be definitively identified as coming from the site is a grog-tempered Poynor Engraved, var. Cook carinated bowl in the Bernie Ward collection (Perttula et al. 2009:6, 11-12 and Figure 5). 


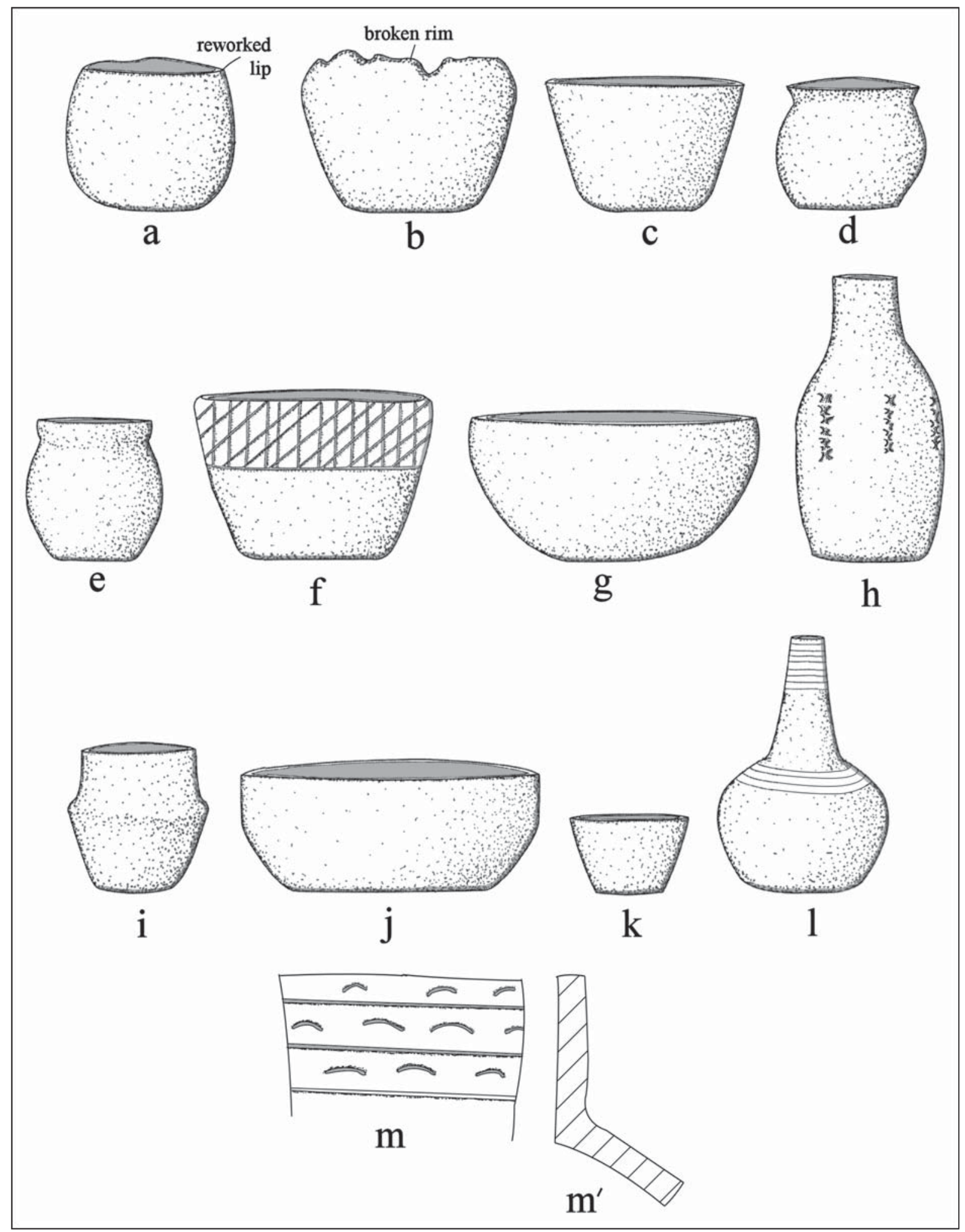

Figure 4. Vessels from Burials 1-6 and Multiple Burial at the Joe Meyer Estate \#1 site: a, Vessel A, Burial 1; b, Vessel B, Burial 2; c, Vessel C, Burial 3; d, Vessel D, Burial 3; e, Vessel F, Burial 3; f, Vessel G, Burial 4; g, Vessel H, Burial 5; h, Vessel I, Burial 5; i, Vessel J, Burial 5; j, Vessel K, Burial 5; k, Vessel L, Burial 6; 1, Vessel M, Multiple Burial; m, Vessel O, Multiple Burial. 

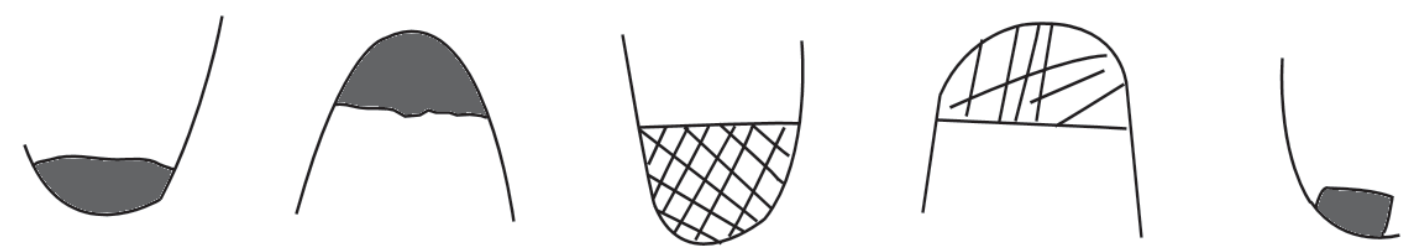

Figure 5. Engraved decorative elements on Vessel E, Burial 3.

\section{Ceramic Sherds}

A sample of 820 ceramic sherds have been collected from the Joe Meyer Estate \#1 site from a series of surface collections and 10 stratigraphic tests excavated by Sam Whiteside of the ETAS (Table 2). These sherds include plain wares ( $\mathrm{n}=489,59.6$ percent of the assemblage), utility wares $(\mathrm{m}=314,38.3$ percent), and fine wares ( $\mathrm{n}=17,2.1$ percent). The sherds are primarily from vessels tempered with grog (79 percent), with lesser amounts of bone temper use (21 percent), based on an examination of 1969 UT and 1969/1970 SMU collections at the Texas Archeological Research Laboratory at The University of Texas at Austin.

Table 2. Ceramic sherd assemblage from the Joe Meyer Estate \#1 site.

\begin{tabular}{lcccc}
\hline & & SMU & \\
$\begin{array}{l}\text { Decorative Method/ } \\
\text { Type }\end{array}$ & $\begin{array}{c}\text { Johnson } \\
(1961)\end{array}$ & $\begin{array}{c}\text { UT } \\
(1969)\end{array}$ & $\begin{array}{c}(1969 / \\
1970)\end{array}$ & Whiteside \\
\hline Plain ware & & & & - \\
Plain rim & 18 & - & - & $108^{*}$ \\
Plain body $\quad$ Subtotal, plain & 320 & 6 & $37^{*}$ & 108
\end{tabular}

\section{Utility ware}

Brushed

Brushed-Incised

Brushed-Punctated

Canton Incised

Davis Incised

Dunkin Incised

Incised, Misc.

Subtotal, incised

2
48
1
9
60

Incised-Punctated

-
-
-
1
1

\section{Fingernail Punctated}

Sinner Linear Punctated

Tool Punctated

Weches Fingernail

Impressed

Punctated, Misc.

-
50
4
-
6


Table 2. Ceramic sherd assemblage from the Joe Meyer Estate \#1 site, cont.

\begin{tabular}{|c|c|c|c|c|}
\hline $\begin{array}{l}\text { Decorative Method/ } \\
\text { Type }\end{array}$ & $\begin{array}{l}\text { Johnson } \\
\text { (1961) }\end{array}$ & $\begin{array}{c}\text { UT } \\
(1969)\end{array}$ & $\begin{array}{c}\text { SMU } \\
(1969 / \\
1970)\end{array}$ & Whiteside \\
\hline \multicolumn{5}{|l|}{ Fine ware } \\
\hline Holly/Hickory Engraved & - & - & - & 3 \\
\hline Holly Fine Engraved & - & - & - & 3 \\
\hline Hickory Engraved & 1 & - & - & - \\
\hline Poynor Engraved & - & - & 1 & 1 \\
\hline Engraved, Misc. & 1 & - & 2 & 2 \\
\hline Subtotal, engraved & 2 & - & 3 & 9 \\
\hline Red-slipped & 1 & - & - & - \\
\hline Trailed & 1 & - & - & 1 \\
\hline Totals & 505 & 11 & 97 & 207 \\
\hline
\end{tabular}

*includes both rim and body sherds

Of the sherds with decorative elements $(n=331)$, most are from utility ware vessels with punctated ( 33.5 percent of the decorated sherds), brushed (32.0 percent), and incised (27.2 percent) decorations (Figure 6b; see also Table 2). Other utility wares in the assemblage have brushed-incised (1.2 percent), brushed-punctated $(\mathrm{n}=0.6$ percent, Figure $6 \mathrm{a})$, and incised-punctated $(0.3$ percent $)$ decorative elements. Fine wares comprise only 5.2 percent of the decorated sherds in the assemblage, primarily sherds with engraved (4.2 percent) designs; the remainder of the fine wares have slipped ( 0.3 percent) and trailed ( 0.6 percent $)$ decorative elements (see Table 2).

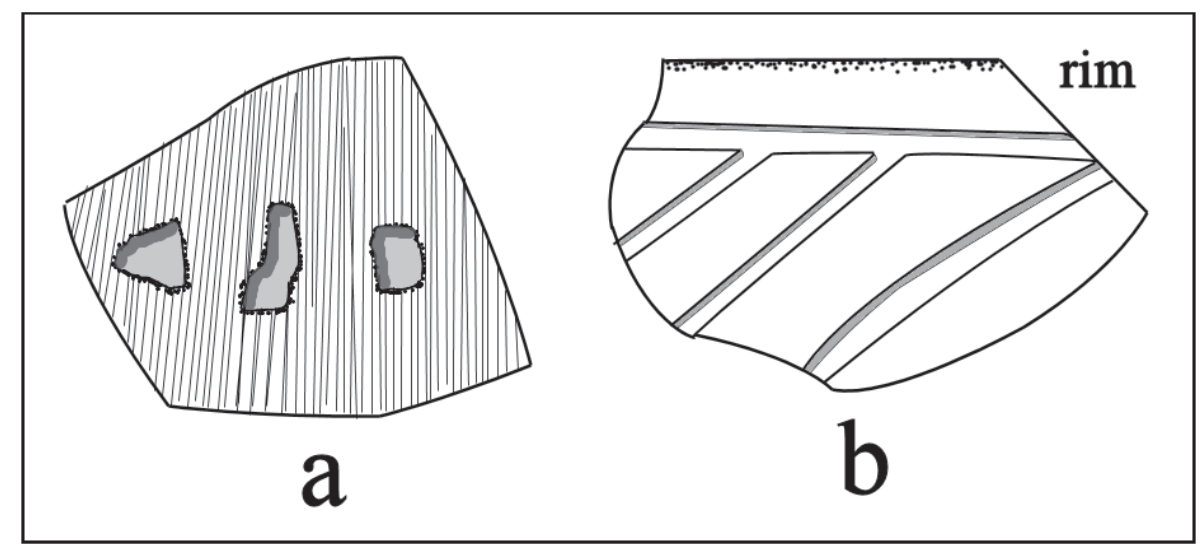

Figure 6. Decorative elements on utility ware sherds: a, brushed-punctated body; $\mathrm{b}$, incised rim.

Recognized types in the decorated sherds from the Joe Meyer Estate \#1 site include Bullard Brushed, Canton Incised, Davis Incised, Dunkin Incised, Weches Fingernail Impressed, Hickory Engraved, Holly Fine Engraved, and Poynor Engraved (see Table 1). Sherds in John Mulligan's collection included those from Davis Incised, Canton Incised, Crockett Curvilinear Incised, and Holly Fine Engraved. With the exception of the Bullard Brushed and Poynor Engraved sherds, which are apparently from Frankston phase habitation areas, the remainder of the identifiable ceramic types in the sherd assemblage are from a ca. A.D. 900-1200 Early Caddo occupation that was contemporaneous with the known burial features (see Figure 3). 


\section{Ceramic Pipe Sherd}

A single pre-A.D. 1400 Red River long-stemmed ceramic pipe stem sherd (see Hoffman 1967) was reported from Strat. Test 4 excavated by Whiteside (TARL inventory sheets). No other details about the pipe stem are available.

\section{Chipped Stone Tools}

There is a small Gary dart point (quartzite) and a gray chalcedony Kent dart point in the collections from the Joe Meyer Estate \#1 site. These dart points indicate that there was some use of the site landform in Woodland period times (ca. 500 B.C. to A.D. 800).

\section{SUMMARY AND CONCLUSIONS}

The Joe Meyer Estate \#1 site is located on an upland ridge overlooking the Saline Creek floodplain, in the upper Neches River basin in East Texas. It was primarily investigated by the East Texas Archeological Society in 1957, but professional archaeologists also visited the site in 1957, 1969, and 1970 as part of large-scale investigations at then proposed Lake Palestine.

While first used by aboriginal peoples sometime during the Woodland period, the principal occupation of the Joe Meyer Estate \#1 site was by ancestral Caddo peoples. The occupation was intensive, as a large and relatively thick midden deposit accumulated on the landform, and it is likely that there are house structural features preserved in the archaeological deposits here. The sherds recovered from the midden deposits are primarily from an Early Caddo period occupation marked by Canton Incised, Davis Incised, Dunkin Incised, and Weches Fingernail Impressed utility ware vessels and Hickory Engraved and Holly Fine Engraved fine ware vessels. There also are Late Caddo period Frankston phase ceramics in the assemblage-including Bullard Brushed and Poynor Engraved - that indicate a second ancestral Caddo occupation at the site, one that took place after ca. A.D. 1400.

In one area of the midden was a rare Early Caddo period (ca. A.D. 900-1200) cemetery with single individual burials and one multiple burial with four individuals. Almost all of the known Caddo cemeteries in the upper Neches River basin date to after ca. A.D. 1300 (Perttula et al. 2011). The multiple burial may have been the latest internment in the cemetery based on its shallow depth in the midden and its position relative to the single row of six individual interments. These burials were oriented generally east-west, with the heads of the deceased facing west towards the House of Death in the Sky (see Hatcher 1927:162; Perttula et al. 2011:403-433). The burials were accompanied by ceramic vessels, between one and four vessels per burial, with an average of 2.1 vessels per burial. One vessel in one of the burials contained a green clay pigment mass and mussel shells.

In addition to the Early Caddo period cemetery, there was also a Late Caddo Frankston phase cemetery at the Joe Meyer Estate \#1 site that may have contained 25+ individuals. Unfortunately, very little information is known about this cemetery, and it apparently was excavated by individuals not affiliated with the East Texas Archeological Society. However, this cemetery was likely contemporaneous with a Frankston phase settlement that is indicated by the recovery of Bullard Brushed and Poynor Engraved sherds in the ceramic assemblage from the site's midden. 


\section{ACKNOWLEDGMENTS}

I would like to thank Jonathan Jarvis for his help in accessing the records and collections from the Joe Meyer Estate \#1 site at the Texas Archeological Research Laboratory at The University of Texas at Austin. Mark Walters reviewed and provided comments on the draft of this article. Lance Trask prepared the figures for this article.

\section{REFERENCES CITED}

Anderson, K. M.

1972 Prehistoric Settlement of the Upper Neches River. Bulletin of the Texas Archeological Society 43:121-197.

Anderson, K. M., K. Gilmore, O. F. McCormick III, and E. P. Morenon

1974 Archaeological Investigations at Lake Palestine, Texas. Contributions in Anthropology No. 11. Department of Anthropology, Southern Methodist University, Dallas.

Hatcher, M. A.

1927 Description of the Tejas or Asinai Indians, 1691-1722, Part IV. Southwestern Historical Quarterly 31:150-180.

Hoffman, M. P.

1967 Ceramic Pipe Style Chronology Along the Red River Drainage in Southwestern Arkansas. The Arkansas Archeologist 8(1):4-14.

Johnson, L., Jr.

1961 An Archeological Survey of Blackburn Crossing Reservoir on the Upper Neches River. Bulletin of the Texas Archeological Society 31:213-238.

Perttula, T. K., D. B. Kelley, and R. A. Ricklis (assemblers and editors)

2011 Archeological Investigations at the Lang Pasture Site (41AN38) in the Upper Neches River Basin of East Texas. Report No. 129. Texas Department of Transportation, Archeological Studies Program, Environmental Affairs Division, Austin.

Perttula, T. K., B. Nelson, and R. Z. Selden, Jr.

2013 Documentation of Cemeteries and Funerary Offerings from Sites in the Upper Neches River Basin, Anderson, Cherokee, and Smith Counties, Texas. Special Publication No. 26. Friends of Northeast Texas Archaeology, Pittsburg and Austin.

Perttula, T. K., M. Walters, S. Marceaux, and B. Nelson

2009 Caddo Pottery Vessels and Pipes from Sites in the Middle and Upper Sabine and Upper Neches River Basins, Smith and Wood Counties, Texas. Special Publication No. 7. Friends of Northeast Texas Archaeology, Pittsburg and Austin.

Walters, $\mathrm{M}$.

2014 East Texas Archeological Society, Tyler, Texas, 1956-1959. Journal of Northeast Texas Archaeology 47:43-90. 